\title{
Nemaline Myopathy 2
}

National Cancer Institute

\section{Source}

National Cancer Institute. Nemaline Myopathy 2. NCI Thesaurus. Code C118784.

An autosomal recessive inherited myopathy caused by mutations in the NEB gene. It is characterized by generalized hypotonia and skeletal muscle weakness. 